\title{
Mechanical Behavior of Polypropylene-based Honeycomb-Core Composite Sandwich Structures
}

\author{
F. E. SEZGin AND M. TANOĞLU* \\ Mechanical Engineering Department, İzmir Institute of Technology, Gülbahce Kampus \\ 35430 Urla-İzir, Turkey \\ O. Ö. EĞILMEZ AND C. DÖNMEZ \\ Civil Engineering Department, İmir Institute of Technology, Gülbahce Kampus \\ 35430 Urla-İzmir, Turkey
}

\begin{abstract}
This article presents results from an experimental study, investigating the effects of core thickness on the mechanical properties of composite sandwich structures with polypropylene(PP)-based honeycomb core and glass fiber-reinforced polymer (GFRP) face-sheets fabricated by hand lay-up technique. Epoxy matrix and non-crimp glass fibers were used for the production of GFRP laminates. Flatwise compression (FC), edgewise compression (EC), three-point bending (3PB) and double cantilever beam (DCB) tests were performed to evaluate the mechanical behavior of the composite sandwich structures (CSSs). Based on the FC tests, an increase in the compressive modulus and strength was observed with an increase in the core thickness. For EC tests, peak loads up to crush of the sandwich panel is discussed using core thickness. According to the 3PB tests, a decrease in core shear stress and facesheet bending stress was observed as the core thickness increases.
\end{abstract}

KEY WORDS: Sandwich structures, honeycomb core, mechanical behavior.

\section{INTRODUCTION}

THE USE OF composite sandwich structures (CSSs) in aerospace and civil infrastructure applications has been increasing, especially due to their extremely low weight that leads to reduction in the total weight and fuel consumption, high flexural and transverse shear stiffness, and corrosion resistance [1-3]. In addition, these materials are capable of absorbing large amounts of energy under impact loads which results in high structural crashworthiness. In its simplest form, a structural sandwich, which is a special form of laminated composite, is composed of two thin, stiff facesheets and a thick lightweight core bonded between them. A sandwich structure will offer different mechanical properties with the use of different constituents. Hence, optimum material choice is often obtained according to the design needs [4-6]. Various combinations of core

*Author to whom correspondence should be addressed. E-mail: metintanoglu@iyte.edu.tr

Journal of Reinforced Plastics And Composites, Vol. 29, No. 10/2010 
and faceplate materials are utilized by researchers worldwide in order to achieve improved crashworthiness [3].

In a sandwich structure/panel, due to the layout of the material the bending loads are carried by the force couple formed by the facesheets, and the shear loads are carried by the core material [7,8]. The facesheets are strong and stiff both in tension and compression as compared to the low-density core material whose primary purpose is to keep the facesheets at a distance in order to maintain a high section modulus (a high 'moment of inertia'). The low density of the core material (e.g., honeycomb or foam) results in low panel density. Under flexural loading, sandwich panels have high specific mechanical properties relative to the overall panel density. Therefore, sandwich panels are highly efficient in carrying bending loads. Additionally, they provide increased buckling and crippling resistance to shear panels and compression members [9]. Under flexural loading, facesheets act together to form a force couple, where one laminate is in compression and the other in tension. The core on the other hand, resists transverse forces and stabilizes the laminates against global buckling and wrinkling (local buckling) [10].

The critical properties of sandwich structures vary according to the application area of the structure. In the automotive industry, the out-of-plane compressive properties are more crucial, whereas in wind turbines the in-plane compressive properties are more important. Therefore, depending on the application area, different properties or characteristics of sandwich panels need to be evaluated $[9,11]$.

There is very limited work in literature that describes the mechanical properties of sandwich composites for structural applications [12]. The objective of this study is to understand the mechanical behavior and failure mechanisms of sandwich structures with polypropylene(PP)-based honeycomb core and glass fiber-reinforced polymer (GFRP) facesheets fabricated by hand lay-up technique as a function of core thickness. This article documents results from flatwise compression (FC), edgewise compression (EC), Mode I interlaminar fracture toughness and three-point bending (3PB) tests conducted on composite sandwich specimens with varying core thicknesses.

\section{MATERIALS, FABRICATION, AND TESTING PROCEDURES}

E-glass non-crimp fabrics, epoxy thermosetting resin, and PP-based honeycomb core materials were used to fabricate the composite sandwich panels. As the reinforcement constituent of composite facesheets, E-glass $0^{\circ} / 90^{\circ}$ biaxial non-crimp fabrics were provided by Telateks Inc., Istanbul, Turkey. Resoltech ${ }^{\mathrm{TM}}$ epoxy resin with an amine hardener was used as the matrix polymer. PP-based core material with hexagonal cell configuration and an average cell size of $5.5 \mathrm{~mm}$ from one corner to the opposite one was used (Figure 1). Five different core thicknesses (5, 10, 15, 20, and $40 \mathrm{~mm}$ ) were used in the fabrication of the sandwich panels.

Sandwich structures were impregnated and laminated by hand lay-up technique. Glass fabrics were wetted by epoxy resin and the core material was laminated with the upper facesheet of the sandwich structure in a mold, coated with a mold release agent. After the lamination procedure, the composites were cured at room temperature under $50 \mathrm{kPa}$ pressure. A post-curing for $2 \mathrm{~h}$ at $100^{\circ} \mathrm{C}$ was applied afterward. 


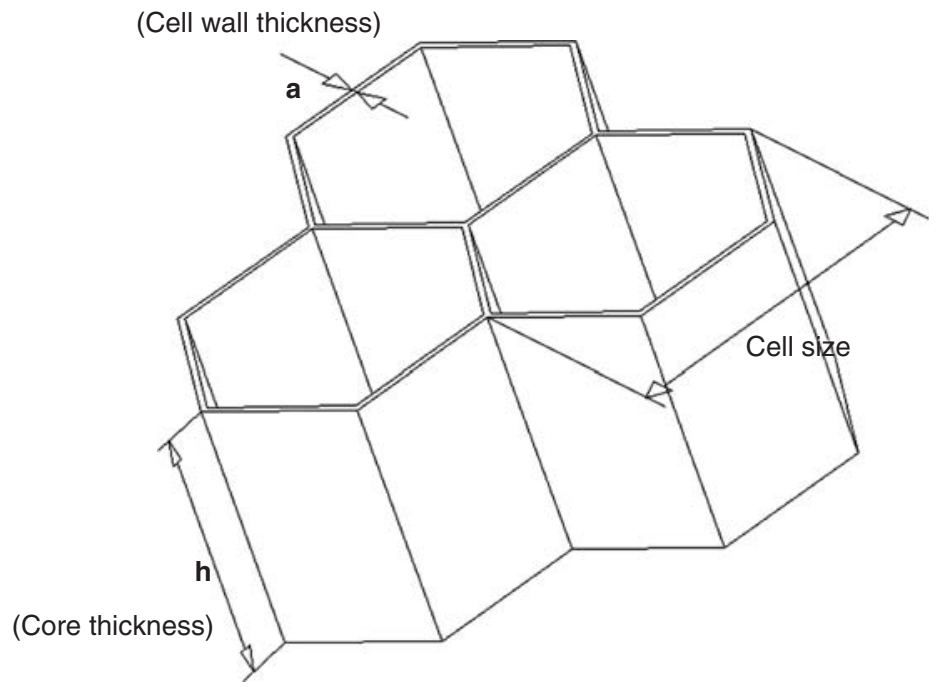

Figure 1. Polypropylene-based honeycomb core representation.

Table 1. Test methods that were used in order to determine the mechanical properties of the composite facesheet, honeycomb core material, and the sandwich structure.

\begin{tabular}{|c|c|c|c|}
\hline Test & Standard & $\begin{array}{l}\text { Testing } \\
\text { speed } \\
(\mathrm{mm} / \mathrm{min})\end{array}$ & Measured properties \\
\hline \multicolumn{4}{|l|}{ Facesheet } \\
\hline Tensile test & ASTM D3039M-93 & 2 & Tensile strength Tensile modulus \\
\hline Flexural test & ASTM 790M-03 & 1.2 & Flexural strength Flexural modulus \\
\hline $\begin{array}{l}\text { Short-beam shear test } \\
\text { Honeycomb core material }\end{array}$ & ASTM D2344-00 & 1 & Interlaminar shear strength \\
\hline Compression test & ASTM C365-00 & 0.5 & $\begin{array}{l}\text { Compression strength Compression } \\
\text { modulus }\end{array}$ \\
\hline \multicolumn{4}{|l|}{ Sandwich structure } \\
\hline Flatwise compression test & ASTM C365-00 & 0.5 & $\begin{array}{l}\text { Compression strength Compression mod- } \\
\text { ulus Energy absorption characteristics }\end{array}$ \\
\hline Edgewise compression test & ASTM C364-99 & 0.5 & $\begin{array}{l}\text { Energy absorption characteristics Collapse } \\
\text { modes Facing compressive stress }\end{array}$ \\
\hline Three-point bending test & ASTM C393-00 & 3 & $\begin{array}{l}\text { Core shear stress Facesheet bending } \\
\text { stress Panel bending stiffness }\end{array}$ \\
\hline Mode I fracture toughness test & ASTM D5528-94a & 5 & $\begin{array}{l}\text { Facesheet/core interface fracture tough- } \\
\text { ness }\end{array}$ \\
\hline
\end{tabular}

Relevant ASTM standards were followed in determining the mechanical properties of the composite constituents and the fabricated sandwich structures. Test specimens were sectioned from the panels using a diamond saw. The tests were conducted by a universal testing machine (Schimadzu ${ }^{\mathrm{TM}}$ AGI). For each test, at least five specimens were tested. Test techniques, ASTM designations, and measured properties are listed in Table 1. 


\section{TEST RESULTS}

\section{Mechanical Behavior of Facesheet Composites}

Tensile, flexural, and short-beam shear tests were carried out on 3-mm thick E-glass fiber/epoxy facesheets of the sandwich structures to determine the tensile, flexural, and interlaminar shear strength, as well as tensile modulus of the facesheet material.

Tensile test was carried out with the 3-mm thick E-glassfiber/epoxy facesheets in order to determine the tensile strength and modulus of the facesheet material. As the facesheet exhibits similiar behavior for $0^{\circ}$ and $90^{\circ}$ directions, only one direction was tested. Typical stress-strain behavior of the composite facesheet under tensile and flexural loading is given in Figure 2. The tensile modulus value of the glassfiber/epoxy facesheets was found to be $14.5 \mathrm{GPa}( \pm 4 \%)$ and the tensile strength was $270 \mathrm{MPa}( \pm 7 \%)$. Flexural strength value of the facesheet material was found to be $490 \mathrm{MPa}( \pm 9 \%)$ and flexural modulus was calculated as $14 \mathrm{GPa}( \pm 2 \%)$. Short-beam shear test was applied to the facesheet material in order to find out the interlaminar shear strength. According to the test results, interlaminar shear strength of the facesheets was $29 \mathrm{MPa}( \pm 3 \%)$.

\section{Mechanical Behavior of PP-Based Honeycomb Core}

The other main component of composite sandwich structures is the PP-based honeycomb core material which is schematically illustrated in Figure 1. The cell-wall thickness values of the honeycomb PP core are given in Table 2. Figures 3(a) and (b) show flatwise compression strength and modulus vs. core thickness data for the PP core material

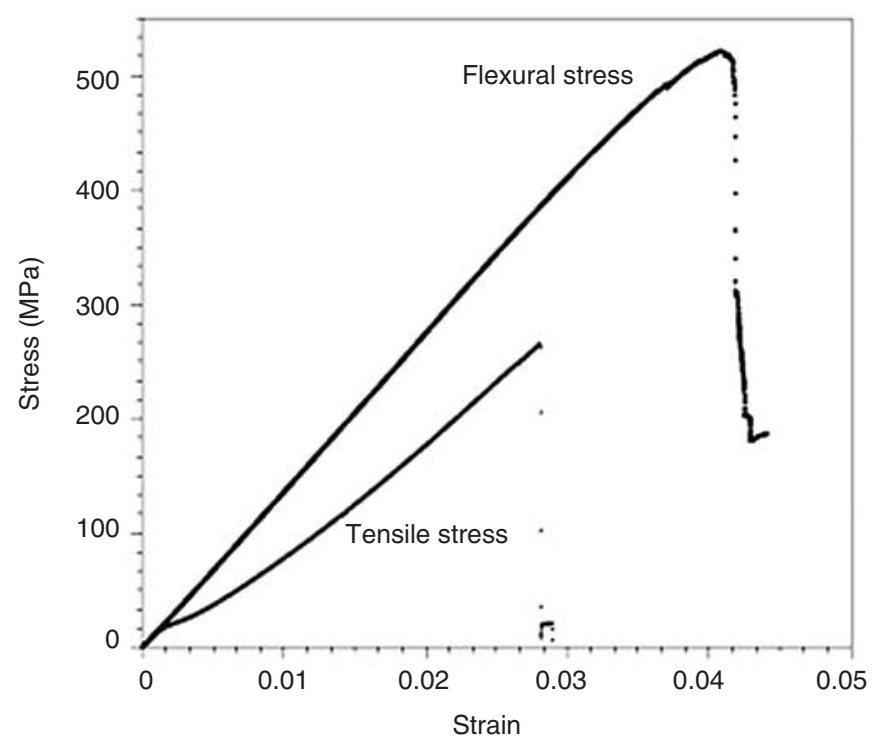

Figure 2. Typical stress-strain behavior of the composite facesheet under tensile and flexural loading. 
obtained from FC tests. It can be observed from Figure 3 that compression strength and modulus of the honeycomb PP core increase as the core thickness increases. At the initial stage of the compression loading, cell walls are observed to deform linearly. Collapse of the core wall due to the local buckling limits the ultimate strength and a relatively sudden

Table 2. Honeycomb core cell wall thickness values for various thicknesses.

\begin{tabular}{lc}
\hline Core thickness $(\boldsymbol{h})(\mathbf{m m})$ & Cell wall thickness $(\boldsymbol{a})(\boldsymbol{\mu m})$ \\
\hline 5 & $209.90( \pm 15.39)$ \\
10 & $220.83( \pm 18.96)$ \\
15 & $233.3( \pm 17.25)$ \\
20 & $262.44( \pm 13.67)$ \\
40 & $260.00( \pm 18.74)$ \\
\hline
\end{tabular}

(a)

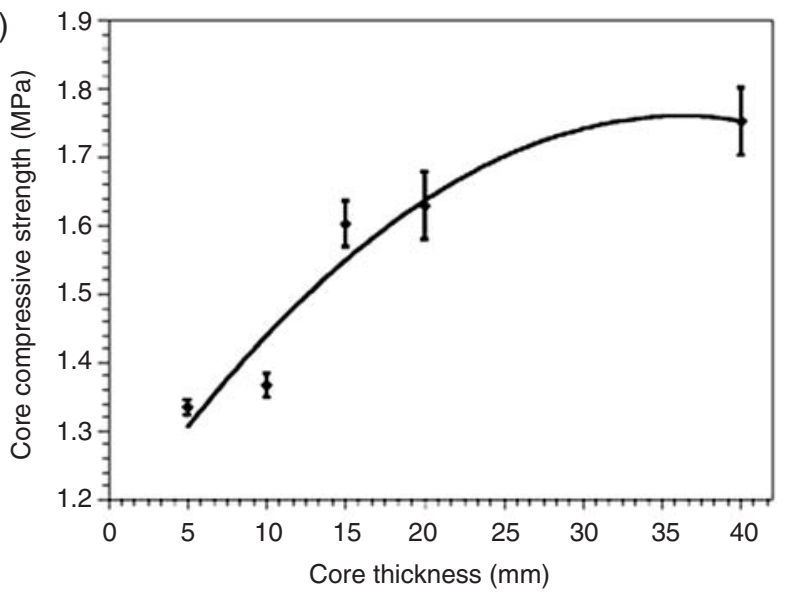

(b)

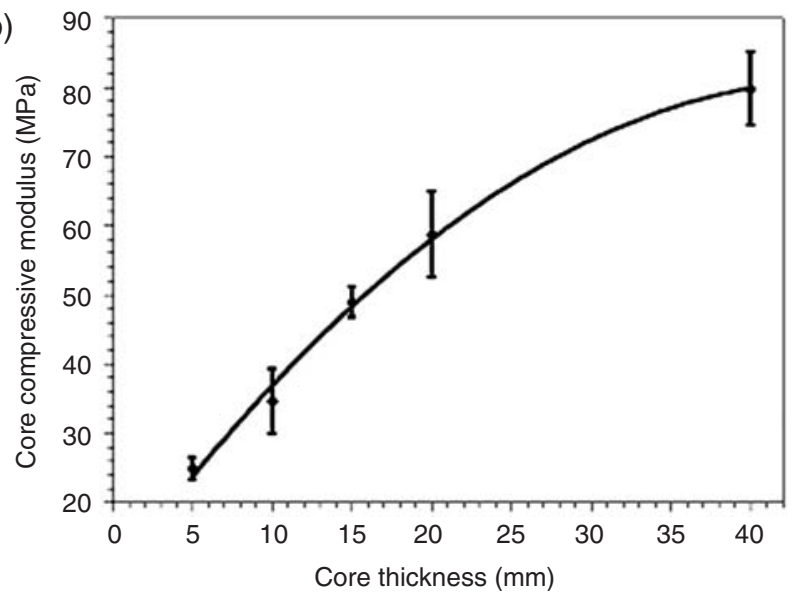

Figure 3. Flatwise compression (a) strength and (b) modulus values of PP-based honeycomb core material as a function of core thickness. 
collapse takes place after the maximum load levels. Similar behavior was reported in literature for similar structures [2].

\section{Mechanical Behavior of Sandwich Structure}

FC and EC, 3PB, and Mode-I fracture toughness tests were conducted on the sandwich structures considered. The load-deformation behavior and collapse sequence images of the CSSs under flatwise loading are presented in Figure 4. Except at the initial load-settling part, it was observed that up to the vicinity of the maximum load level, a linear loaddeformation relation exists. Beyond the maximum load level, the system collapsed and a large drop in the load levels occurred. It was observed that the cause of the drop is the bending and local buckling of the cell walls. After the drop, the load picked up with a small slope after the initial drop. The cause of the increase in load capacity at this stage is the densification of the folded cell walls. In Figure 4(b), specific crash energy absorption (absorbed energy/weight of the composite, $E_{\mathrm{s}, \mathrm{a}}$ ) is also illustrated. When collapse occurs, energy absorption rate changes as the slope of the $E_{\mathrm{s}, \mathrm{a}}$ curve decreases. The behavior of the structure under compressive loads is also illustrated by the images given in Figure 4(a).

(a)

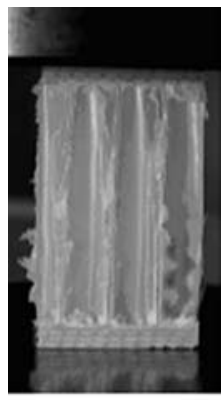

$1 \mathrm{~mm}$

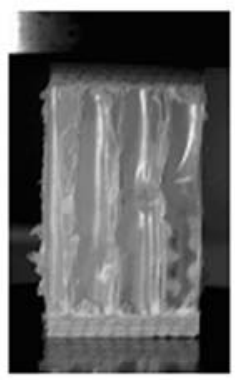

$2 \mathrm{~mm}$

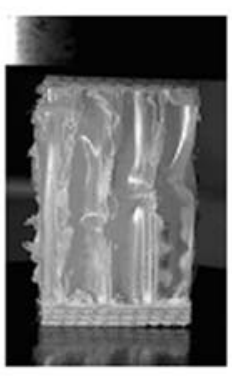

$4 \mathrm{~mm}$

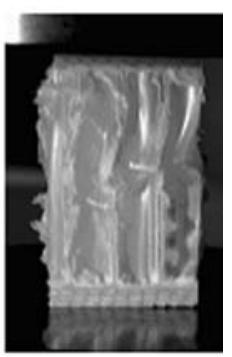

$6 \mathrm{~mm}$

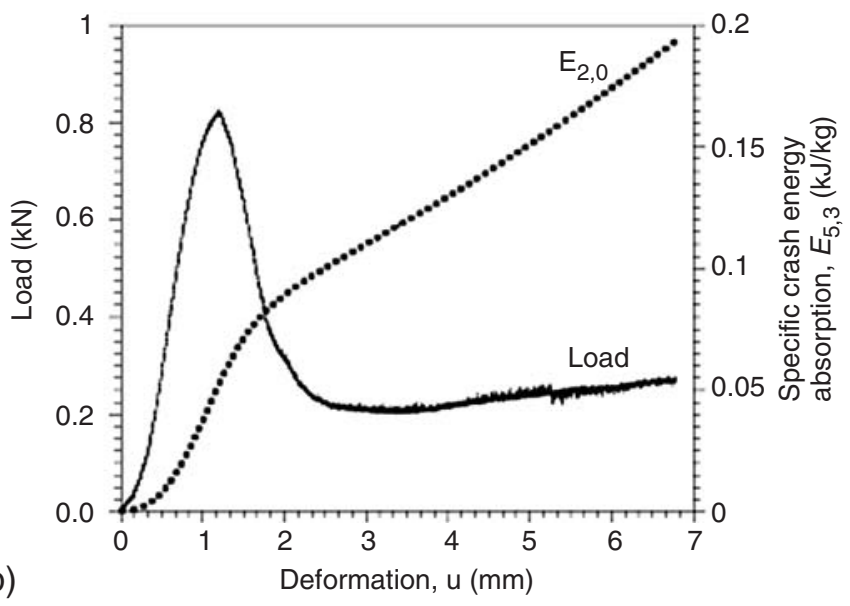

Figure 4. Behavior of composite sandwich structures with honeycomb core material and glassfiber/epoxy facesheets under flatwise loading: (a) collapse sequence images and (b) loaddeformation graph of the test specimen and the specific crash energy absorption, $E_{s, a}$ graph during the test. 
As seen in the first picture, at the initial stage, no bending at the cell walls is observed. After the maximum load level, bending of the cell walls occurs.

Figure 5 shows the FC modulus values given as a function of core thickness. As seen from the figure, the compression modulus values increase with increasing core thickness. This behavior is analogous to the behavior observed in FC tests of the constituent core material (Figure 3) since the FWC properties of sandwich structures are dependent on the core material behavior [2]. The increase of the modulus with the increase of cell wall thickness $(a)$, is similar to that given in Figure 3 for the PP core itself.

EC tests were also conducted on the sandwich structures with different core thicknesses and their mechanical behaviors were evaluated. Collapse sequence images and the typical load-deformation graph and specific absorbed crash energy variation of a typical sandwich structure are given in Figure 6. Absorbed crash energy was calculated from the area under the load-deformation curve. Facesheets are the main load-carrying members under EC loading. The core material increases the strength of the system by coupling the facesheets to each other and increasing the buckling load. The load-deformation curve (Figure 6(b)) has a linear portion at the beginning. Afterwards, cell wall buckling within the sandwich panel started with the de-bonding of the core and facesheets at the edge of the panels in contact with the crossheads. Failure occurred due to shear at the interface between the core and the stiffer facesheet laminate, on the compression side of the core. On the opposite side, that is, under tension, the core remained perfectly bonded to the facesheet. The deflection of the panel increased as the load was applied and the panel slid from the core material, which caused high frictional resistance. At large deformation ratios, facesheets fractured. The fracture of the facesheets started from the face with tension and continued through the thickness. This mode of collapse is called 'sandwich panel column buckling' as is reported in the literature too [3]. At this stage, bending resistance of the sandwich structure decreases, which also causes the decrease of crash energy absorption.

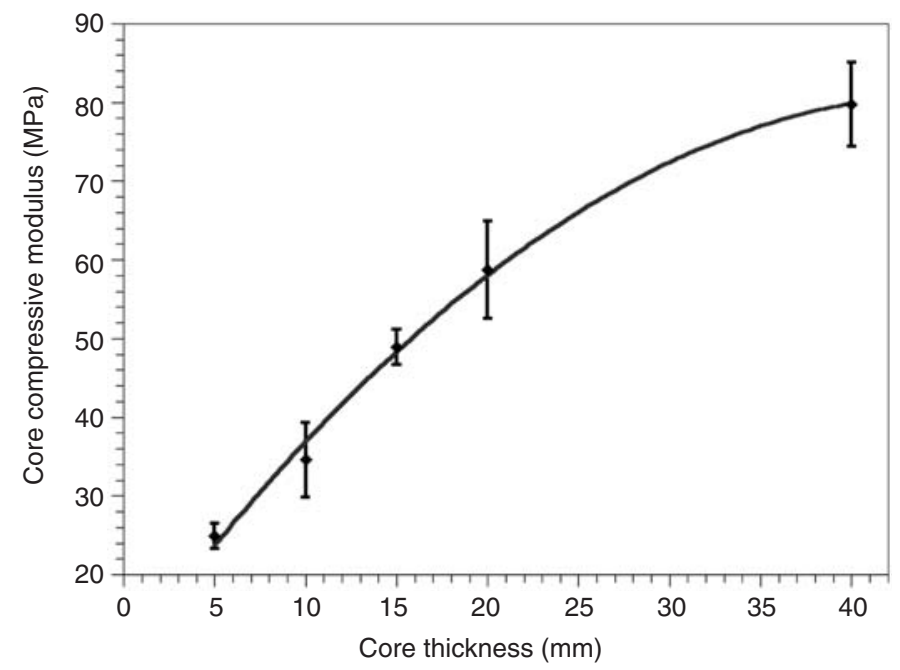

Figure 5. Flatwise compession modulus change as a function of core thickness of honeycomb cored, E-glassfiber/epoxy composite sandwich structures under flatwise compression loads. 
(a)

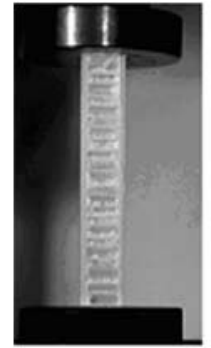

$1 \mathrm{~mm}$

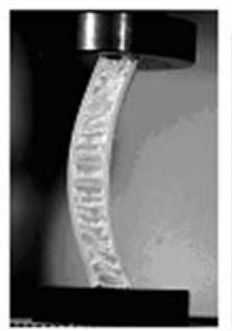

$5 \mathrm{~mm}$

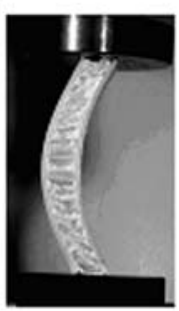

$10 \mathrm{~mm}$

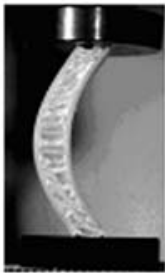

$15 \mathrm{~mm}$

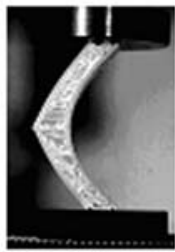

$25 \mathrm{~mm}$

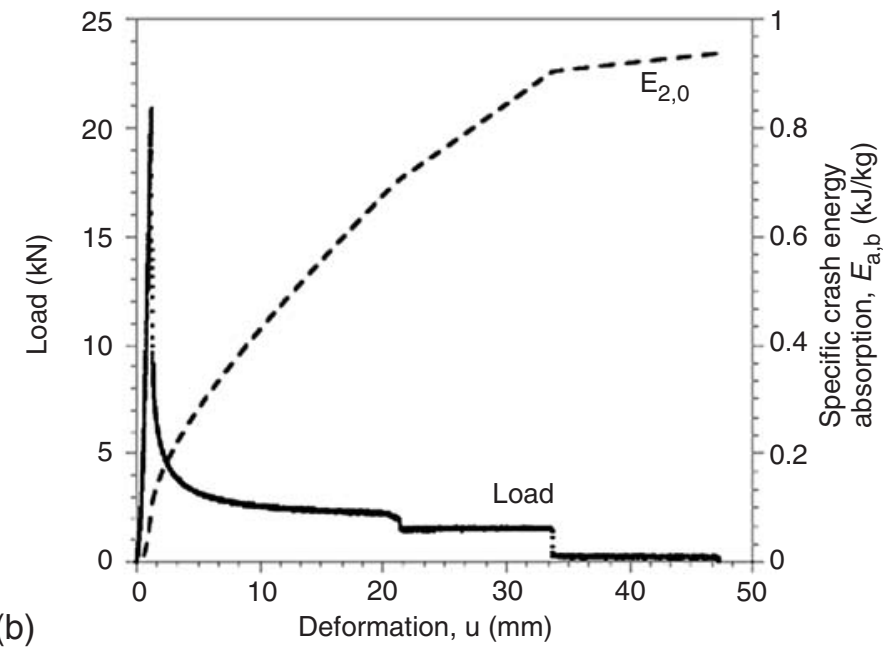

Figure 6. Behavior of composite sandwich structures with honeycomb core material and glass fiber/epoxy facesheets under edgewise loading: (a) collapse sequence images of the specimen and (b) load-deformation graph of the test specimen and the specific crash energy absorption, $E_{s, a}$ during the test.

Three-point bending test was applied to the sandwich structures in order to evaluate the core shear stress and facesheet bending stress variation in accordance with the core thickness increase. It can be seen from Figure 7(a) and (b) that core shear stresses at the peak load decreased as the core thickness increased. On the other hand, it can be observed from Figure 8 that panel bending stiffness at the initial linear portion increases with increasing core thickness.

Core material/facesheet plate interface fracture toughness values were evaluated by Mode-I fracture toughness test. In Figure 9, Mode-I fracture toughness values of the composites for various core thickness are given as a function of delamination length increase. The average crack initiation values are about $80 \mathrm{~J} / \mathrm{m}^{2}$ for each core thickness and the crack propagation values are roughly $800,600,1000,500$, and $900 \mathrm{~J} / \mathrm{m}^{2}$ for $5,10,15,20$, and $40 \mathrm{~mm}$ core thicknesses, respectively. It was observed that there is no significant relation between core thickness increase and fracture toughness values as expected. Fracture toughness value is not related to the honeycomb core and cell wall thickness increments. The fracture mode was observed to be a continuous crack growth. 

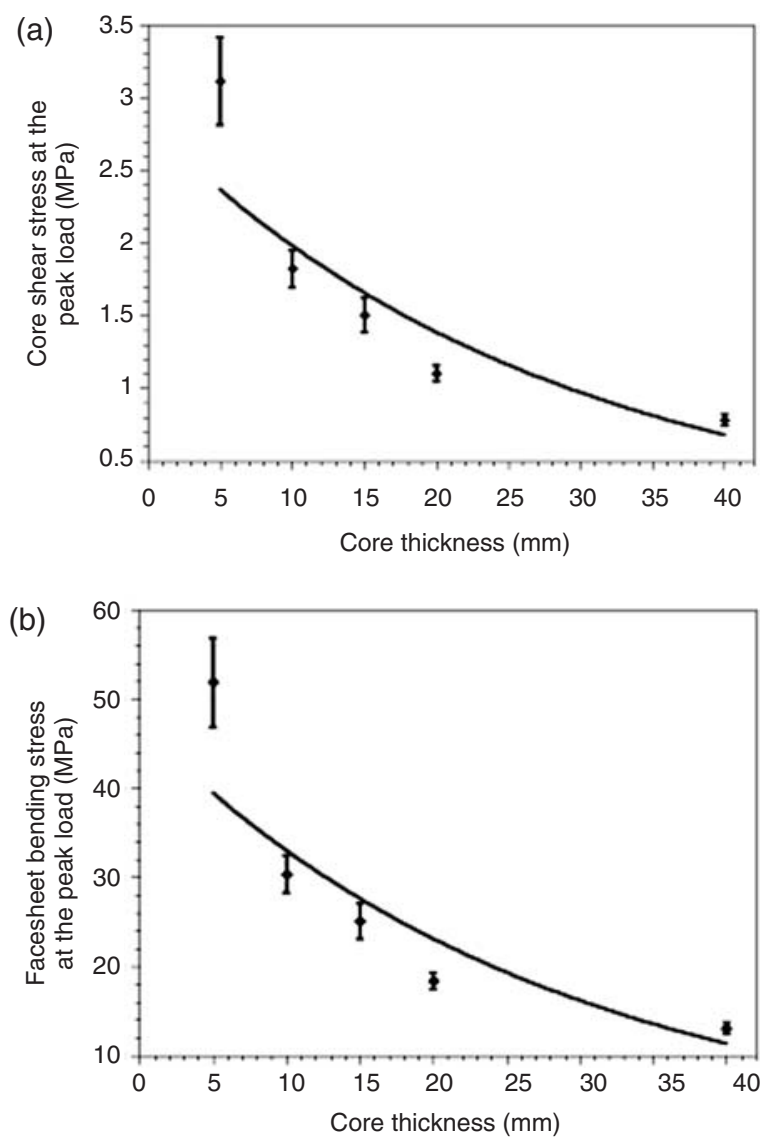

Figure 7. Behavior of composite sandwich structures with honeycomb core material and glassfber/epoxy facesheets under three-point bending loading (a) core shear stress at the peak load, (b) facesheet bending stress variation with the core thickness increment.

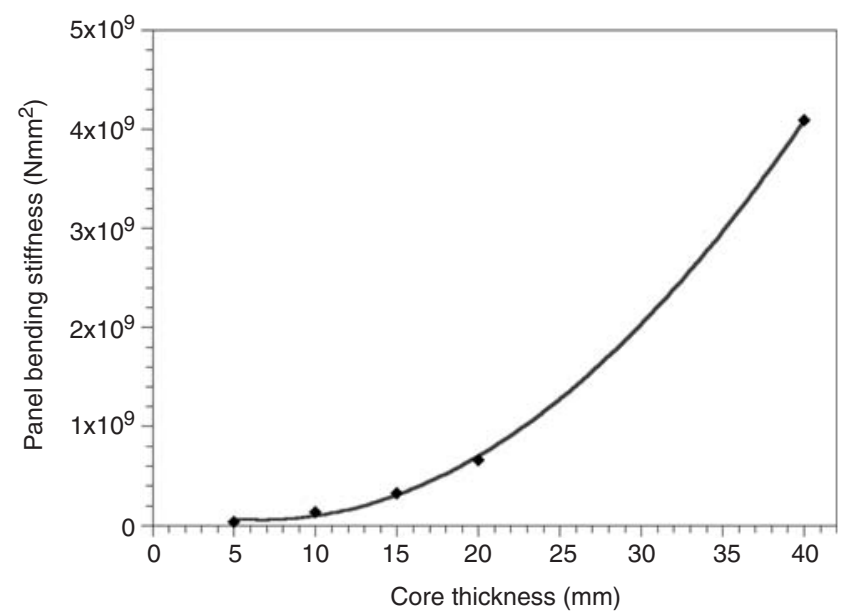

Figure 8. Variation of the panel bending stiffness of composite sandwich structures with honeycomb core material and glassfber/epoxy facesheets under three-point bending loading in accordance with core thickness increment. 


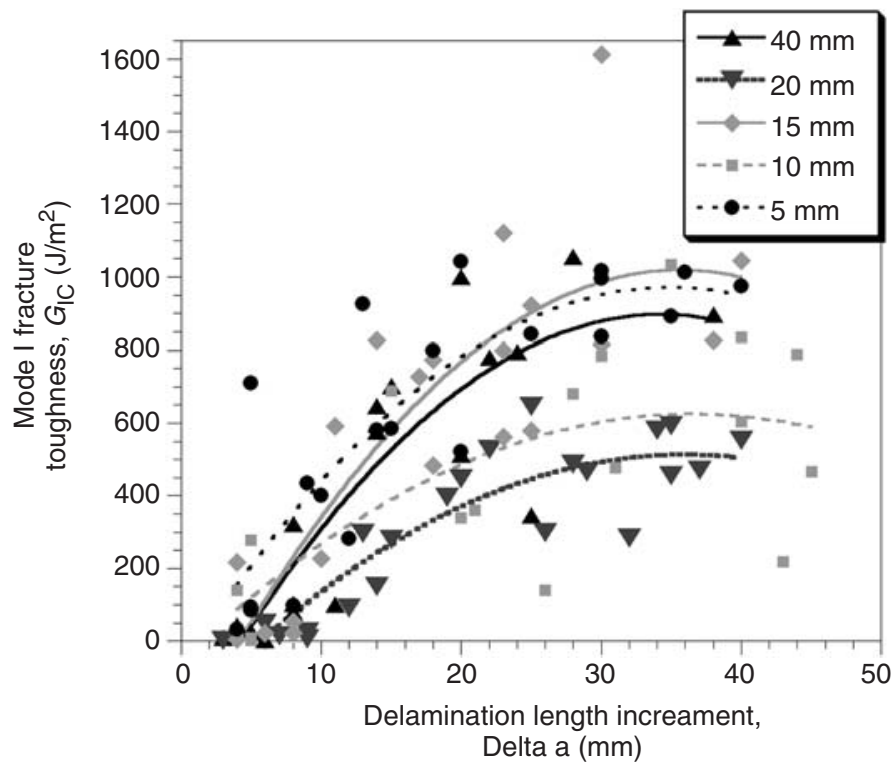

Figure 9. Core material/facesheet interface Mode-l fracture toughness value variation with the core thickness increment.

\section{CONCLUSION}

In this study, the mechanical properties of composite sandwich structures fabricated with E-glass fiber/epoxy facesheet and PP-based honeycomb core are evaluated. The individual behavior of the honeycomb core material and glass fiber/epoxy facesheets are also determined by performing standard tests on these materials.

Application of the FC tests to the core material showed that core material compression strength and modulus increased with the core thickness as a result of increase of honeycomb cell wall thickness. In the Fc test, honeycomb-core cell walls buckled locally and densified.

In the FC test, composite sandwich structures with honeycomb core material deformed similarly with the core material itself. It was observed that only the core material influences the FC properties of the sandwich panel. Under the EC loading of sandwich structures, facesheets buckled and failure occurred at large deformation values. In the EC test, sandwich panel column buckling collapse mode, which is not the most efficient mode for crash energy absorption, was observed.

Three-point bending test results showed that core shear stress and facesheet bending stress at the peak load decrease while the panel bending stiffness increases with the core thickness increments.

\section{REFERENCES}

1. Shivakumar, K., Chen, H. and Smith, A. (2005). An Evaluation of Data Reduction Methods for Opening Mode Fracture Toughness of Sandwich Panels, Journal of Sandwich Structures and Materials, 7: 77-90.

2. Borsellino, C., Calabrese, L. and Valenza, A. (2004). Experimental and Numerical Evaluation of Sandwich Composite Structures, Composite Science and Technology, 64: 1709-1715. 
3. Mamalis, A. G., Manolakos, D. E., Ioannidis, M. B. and Papapostolou, P. D. (2005). On the Crushing Response of Composite Sandwich Panels Subjected to Edgewise Compression: Experimental, Composite Structures, 71: 246-257.

4. Van Vuure A. W., Pflug, J., Ivens, J. A. and Verpoest, I. (2000). Modelling the Core Properties of Composite Panels Based on Woven Sandwich-Fabric Preforms, Composite Science and Technology, 60: 1263-1276.

5. Ural, A., Zehnder, A. T. and Ingraffea, A. R. (2003). Fracture Mechanics Approach to Facesheet Delamination in Honeycomb: Measurement of Energy Release Rate of the Adhesive Bond, Engineering Fracture Mechanics, 70: 93-103.

6. Liang, S. and Chen, H. L. (2006). Investigation on the Square Cell Honeycomb Structures Under Axial Loading, Composite Structures, 72: 446-454.

7. Barbero, E. and Ganga Rao, H. V. S. (1991). Structural Applications of Composites in Infrastructure, Part I. SAMPE Journal, 27(6): 9-16.

8. Cantwell, W. J., Scudamore, R., Ratcliffe, J. and Davies, P. (1999). Interfacial Fracture in Sandwich Laminates, Composite Science and Technology, 59: 2079-2085.

9. Adams, D. F. (2006). Sandwich Panel Test Methods, High Performance Composites 2006. (cited 2006 January 6). Available at: http://www.compositesworld.com/columns (accessed June 16, 2009).

10. Norlin, P. and Reuterlöv, S. (2002). The Role of Sandwich Composites in Turbine Blades, Reinforced Plastics, 32-34.

11. Engineered Materials Handbook, Vol. 1, Composites (1987), pp. 721-728, AMS International, Metals Park, Ohio.

12. Nguyen, M. Q., Jacombs, S. S., Thomson, R. S., Hachenberg, D. and Scott, M. L. (2005). Simulation of Impact on Sandwich Structures, Composite Structures, 67: 217-227. 